\title{
Morphometric characteristics of lumbar vertebral pedicles in Mexican population. Implications for transpedicular lumbar fusion surgery
}

\author{
CASTRO-REYES, C.D. ${ }^{1}$, MORALES-AVALOS, R. ${ }^{1}$, VIILCHEZ-CAVAZOS, F. $^{2}$, \\ DE LA GARZA-CASTRO, $\mathrm{O}^{1}$, SALINAS-ZERTUCHE, A. ${ }^{1}$, \\ AGUIRRE, P.O.M. ${ }^{3}$, CÁMARA-RODRÍGUEZ, L. ${ }^{3}$, VIDAL-TORRES, O. ${ }^{3}$, \\ ELIZONDO-OMAÑA, R.E. ${ }^{1 *}$ and GUZMÁN-LÓPEZ, S. ${ }^{1}$
}

\author{
${ }^{1} \mathrm{MD}$, PhD, Professor, Departament of Human Anatomy, Faculty of Medicine, Universidad Autónoma de Nuevo \\ León, Ave. Madero, s/n, Col. Mitras Centro, Z.C 64460, Monterrey, Nuevo León, Mexico \\ ${ }^{2} \mathrm{MD}, \mathrm{PhD}$, Professor, Orthopedics and Traumatology Service, University Hospital "Dr. José Eleuterio González", \\ Universidad Autónoma de Nuevo León, Ave. Madero, s/n, Col. Mitras Centro, Z.C 64460, \\ Monterrey, Nuevo León, Mexico \\ ${ }^{3}$ Medicine Student, Faculty of Medicine, Universidad Autónoma de Nuevo León, Ave. Madero, s/n, \\ Col. Mitras Centro, Z.C 64460, Monterrey, Nuevo León, Mexico \\ *E-mail: rod_omana@yahoo.com
}

\begin{abstract}
Introduction. Spinal fusion surgery using transpedicular fixation is the most common technique for surgical treatment of spinal pathologies of any etiology. The morphometric characteristics of the vertebral pedicle determine the size and shape of pedicle implants. The objective of this study is to determine the morphometric characteristics of the lumbar vertebral pedicle in Mexican population by direct measurement of bone parts. Materials and Methods. We analyzed $65 \mathrm{Ll}-\mathrm{L} 5$ cadaver lumbar spines from a collection of bone specimens from the Department of Human Anatomy. Pedicle width, height, and length were determined bilaterally in each sample studied. We obtained measures of central tendency, and parametric correlation tests were performed with a $95 \%$ confidence interval to determine if significant differences exist between the lumbar vertebral levels. Results. Pedicle width increased from Ll to L5. We obtained a minimum mean value of $7.40 \pm 1.84 \mathrm{~mm}$ at L1 and a maximum mean value of $14.74 \pm 3.77 \mathrm{~mm}$ at L5. Pedicle height decreased from L1 to L4 with a subsequent increase at L5. We obtained a maximum mean value of $18.32 \pm 4.15 \mathrm{~mm}$ at L5 and minimum mean value of $14.09 \mathrm{~mm} \pm 2.75$ at L4. Significant differences were observed $(P<0.05)$ when groups were compared. Conclusions. This study accurately describes the morphometric characteristics of the lumbar vertebral pedicle. These data will be useful for correct selection and positioning of transpedicular screws.
\end{abstract}

Keywords: vertebra, pedicle, morphometry, lumbar, transpedicular approach.

\section{Introduction}

One of the options available for surgical treatment of lumbar spine pathology is transpedicular instrumentation. Spinal fusion surgery via transpedicular fixation is the most commonly used technique for surgical treatment of degenerative, vascular, infectious, metastatic, congenital, and traumatic pathologies affecting the lumbar spine. In the last two decades, this procedure has displaced most other fusion techniques (PRAKASH PRABHU, RAJANIGANDHA, MANGALA et al., 2007; ARMAN, NADERI, KIRAY et al., 2009). In 2003, it became the nineteenth most performed surgical procedure in the United States, and it increased from 22 to 51 procedures performed per 100,000 inhabitants (SANTONI, HYNES, MCGILVRAY et al., 2008).

The procedure involves the introduction of pedicle screws through a point located at the junction of the transverse process and the superior articular process. The screw crosses the pedicle to reach the vertebral body providing stability and internal fixation of the affected vertebral segment. It is also used as an access for procedures performed within the vertebral body, such as biopsies or vertebroplasty (LIEN, LIOU and WU, 2007).

Among the advantages of this procedure are stabilization of affected vertebral segments, biomechanical superiority of this system, potential three-dimensional correction of vertebral deformities, reduction of postoperative complications and a shorter hospital stay, and greater clinical improvement (GÓMEZ DE LA RIVA, ISLA, PÉREZ-LÓPEZ et al., 2006). Mortality from this procedure is less than $1 \%$; however, retrospective studies have shown that lumbar pedicle fractures occur in $29 \%$ of patients undergoing transpedicular spinal fusion surgery. This causes a reduction in the fixation rate of affected vertebral segments and produces a higher incidence of acute and chronic complications related to surgery (CASTRO, HALM, JEROSCH et al., 1996; WEINSTEIN, SPRATT, SPENGLER et al., 1988).

The morphometric characteristics of the vertebrae, and especially the pedicle, determine the size of pedicle implants both in width and length, and the shape, direction, and ideal 
screw angulation at the moment of introduction (OLMOS, VILLAS TOMÉ, BEGURISTAN GURPIDE et al., 2002). Knowledge of these features is important for the surgeon to avoid pedicle cortex, meningeal, nerve root, facet joint, viscera or adjacent vascular structure lesions due to poor placement or improper screw orientation (OKUTAN, KAPTANOGLU, SOLAROGLU et al., 2004; FEMENIAS ROSELLO, ESTELLA RIPOLL, RUBI JAIME et al., 2009).

There are no studies to date in cadaveric specimens that analyze the morphometric characteristics of the lumbar vertebral pedicle in Mexican population, with this being of great importance for the proper planning, execution, and outcome of transpedicular lumbar spinal fusion. The aim of this study is to determine the morphometric characteristics of the lumbar vertebral pedicle in Mexican population by direct measurement of bone specimens.

\section{Materials and Methods}

We performed an observational, cross-sectional, descriptive, and comparative study by analyzing 65 dried lumbar spines, L1 to L5 (325 vertebrae, 650 pedicles), from cadavers belonging to a collection of osteological specimens of the Department of Human Anatomy, of the School of Medicine of the Autonomous University of Nuevo Leon. We excluded specimens with structural damage, pathology, or an evident abnormality. Data were collected from each studied sample with a digital vernier with an accuracy of $0.01 \mathrm{~mm}$. All measurements were reported in millimeters.

Pedicle height and width were determined bilaterally at the pedicle isthmus (narrowest portion of the vertebral pedicle) in each sample studied, and pedicle length was carried out using the following measurement parameters (Figure 1):

- Pedicle cortical width: distance between both lateral edges of the cortices of the vertebral pedicle.

- Cortical pedicle height: distance between the upper border of the upper cortical and the lower border of the lower cortical vertebral pedicle.

- Pedicle length: distance between the junction of the transverse process and the superior articular process at the point where the pedicle contacts the vertebral body.

\subsection{Statistical analysis}

Measurement parameters were analyzed using Microsoft Excel 2013 for Windows XP. Means, standard deviation, and minimum and maximum values for each parameter measured were obtained and tables were constructed using these data. We determined if significant differences existed between the mean values of the various parameters studied between adjacent lumbar vertebral levels (L1 vs. L2, L2 vs. L3 , L3 vs. L4 and L4 vs. L5) using a parametric correlation test (Student's $t$ test), considering a $\mathrm{P}$ value $<0.05$ as significant.

\subsection{Ethical considerations}

The protocol was approved by the local Health Research Committee with registration no. AH07-005.

\section{Results}

Pedicle cortical width showed a gradual increase from Ll to L5 with results varying between 3 and $25 \mathrm{~mm}$. We obtained a minimum mean score of $7.40 \pm 1.84 \mathrm{~mm}$ in $\mathrm{Ll}$ and a maximum mean value of $14.74 \pm 3.77 \mathrm{~mm}$ at L5. In the same way, standard deviation values showed a progressive increase from L1 to L5 (Table 1).

Table 1. Morphometric analysis of the width, height, and length of the pedicle cortical from L1 to L5. Results are expressed in millimeters.

\begin{tabular}{crccc}
\hline Vertebral & \multicolumn{5}{c}{ Pedicle width } \\
\cline { 2 - 5 } level & mean & minimum & maximum & SD \\
\hline L1 & 7.40 & 3.41 & 12.06 & \pm 1.64 \\
L2 & 7.82 & 5.07 & 11.64 & \pm 1.77 \\
L3 & 9.19 & 5.49 & 14.18 & \pm 2.10 \\
L4 & 10.72 & 5.44 & 19.52 & \pm 2.44 \\
L5 & 14.74 & 6.50 & 24.66 & \pm 3.77 \\
\hline Vertebral & \multicolumn{5}{c}{ Pedicle height } \\
level & mean & minimum & maximum & SD \\
\hline L1 & 15.24 & 9.41 & 18.93 & \pm 1.90 \\
L2 & 14.63 & 12.61 & 17.28 & \pm 1.24 \\
L3 & 14.56 & 10.90 & 20.18 & \pm 1.92 \\
L4 & 14.09 & 9.85 & 20.73 & \pm 2.75 \\
L5 & 18.32 & 10.95 & 29.47 & \pm 4.15 \\
\hline Vertebral & \multicolumn{5}{c}{ Pedicle length } \\
level & mean & minimum & maximum & SD \\
\hline L1 & 9.18 & 4.45 & 26.00 & \pm 6.36 \\
L2 & 9.15 & 4.46 & 24.00 & \pm 5.92 \\
L3 & 8.49 & 3.84 & 20.50 & \pm 4.99 \\
L4 & 7.91 & 3.35 & 20.00 & \pm 4.69 \\
L5 & 7.81 & 3.09 & 19.04 & \pm 5.15 \\
\hline SD
\end{tabular}

SD, standard deviation.
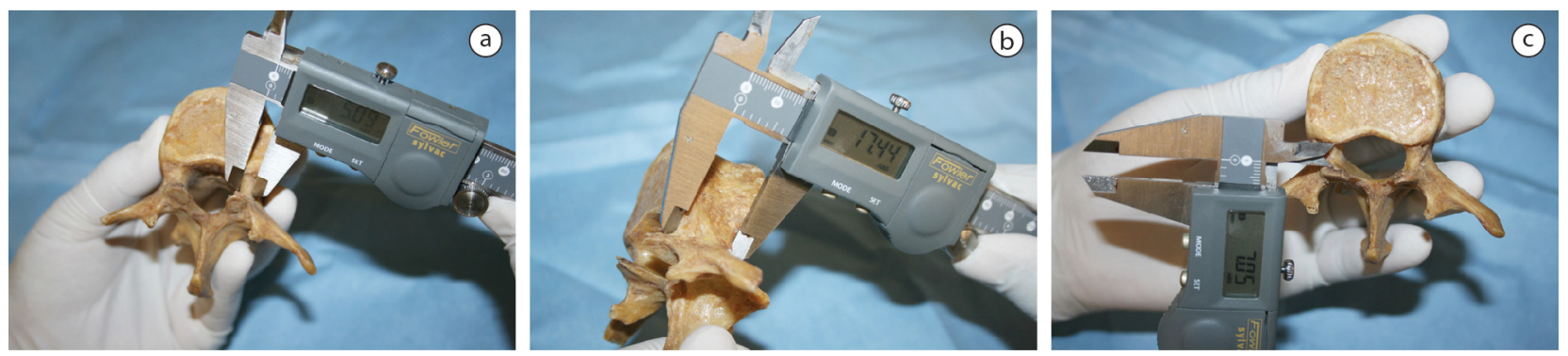

Figure 1. (a) Measurement of pedicle height. (b) Measurement of pedicle length. (c) Measurement of pedicle width. 
Cortical pedicle height decreased from $\mathrm{Ll}$ to $\mathrm{L} 4$ with results varying between 9 and $30 \mathrm{~mm}$. We obtained a maximum mean value of $15.24 \pm 9.41 \mathrm{~mm}$ in $\mathrm{Ll}$ and a minimum mean value of $14.09 \mathrm{~mm} \pm 2.75 \mathrm{in} \mathrm{L4}$. The maximum mean result of all lumbar levels was evident at L5 with a value of $18.32 \pm 4.15 \mathrm{~mm}$ (Table 1$)$.

Pedicle length varied between 3 and $26 \mathrm{~mm}$ with a mean minimum value of $7.81 \pm 5.15 \mathrm{~mm}$ at $\mathrm{L} 5$ and a mean maximum value of $9.18 \pm 6.36$ at $\mathrm{Ll}$. In the same way, pedicle length was the parameter with the highest standard deviation of the study, which was greater at $\mathrm{Ll}$ with a value of \pm 6.36 (Table 1 ).

Significant differences were observed when comparing each mean result of the comparison groups (L1 vs. L2, L2 vs. L3, L3 vs. L4, and L4 vs. L5) using a two-tailed $t$ test in which a $P$ value $<0.05$ was considered significant, with most belonging to pedicle width (Table 2 ).

\section{Discussion}

The pedicle is the strongest portion of the vertebrae. Because of this, transpedicular instrumentation of the spine has demonstrated biomechanical superiority over other available posterior instrumentation techniques (CHAZONO, TANAKA, KUMAGAE et al., 2012) (Figure 2).

In recent decades, there have been numerous studies of the morphometric characteristics of the lumbar vertebral pedicle in different populations around the world to determine

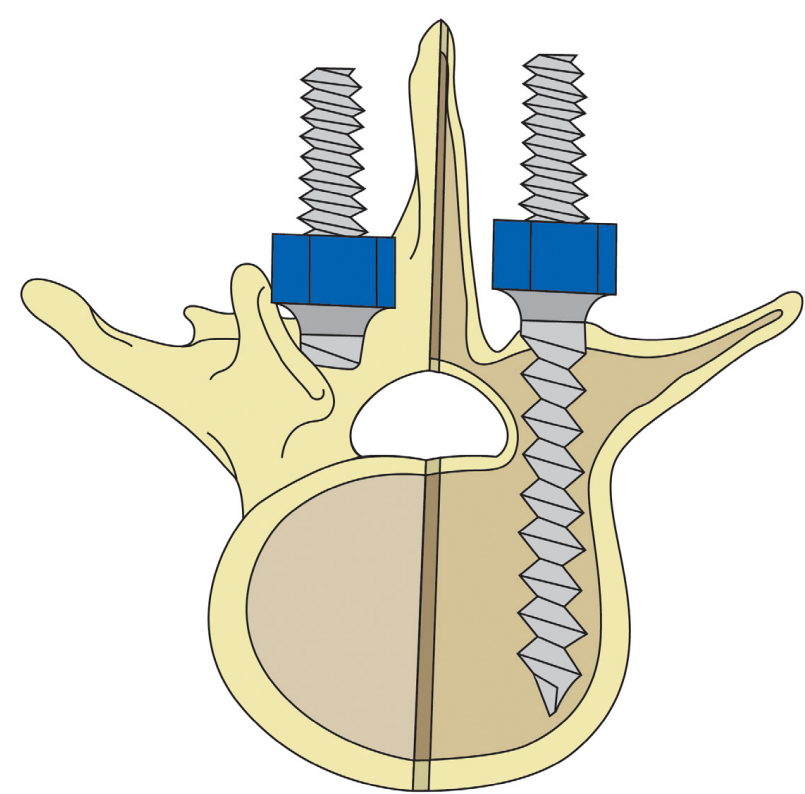

Figure 2. Representative diagram of transpedicular instrumentation applied to a lumbar vertebra. their true dimensions by direct measurement in dry cadaver vertebrae, measurement with computed tomography (CT), radiography, fluoroscopy, and three-dimensional reconstruction. These studies have demonstrated significant differences in the different ethnicities, races, genders, ages, and vertebral regions studied (CHAZONO, TANAKA, KUMAGAE et al., 2012).

In the present study, cortical pedicle width showed a gradual increase from Ll to L5; in the same way it was shown that there was more variation in results as the lumbar vertebral level fell, which was demonstrated when the results of standard deviations were analyzed. (URRUTIA VEGA, ELIZONDO-OMAÑA, DE LA GARZA-CASTRO et al., 2009) evaluated lumbar vertebral pedicle width in Mexican population using computed tomography (CT) reporting a minimum mean value of $7.8 \mathrm{~mm} \pm 1.3 \mathrm{in} \mathrm{Ll}$ and an mean maximum of $14.3 \pm 1.8 \mathrm{~mm}$ at L5, very similar results to those obtained in this study and which represent the only data available for our population with regard to lumbar vertebral pedicle morphometry. This also shows that data obtained in cadavers by CT and direct measurements are very similar (URRUTIA-VEGA, ELIZONDO-OMAÑA, DE LA GARZACASTRO et al., 2009; MORALES AVALOS, ELIZONDOOMAÑA, VÍLCHEZ-CAVAZOS et al., 2012).

The results of pedicle cortical width in different populations are shown in Table 3 and Figure 3. As can be seen, these studies showed a progressive increase in width from L1 to L5 (OLMOS, VILLAS TOMÉ, BEGURISTAN GURPIDE et al., 2002; OKUTAN, KAPTANOGLU, SOLAROGLU et al., 2004; FEMENIAS-ROSSELLÓ, ESTELLA RIPOLL, RUBI JAIME et al., 2009; CHAZONO, TANAKA, KUMAGAE et al., 2012; URRUTIA VEGA, ELIZONDO-OMAÑA, DE LA GARZA-CASTRO et al., 2009; LIEN, LIOU and WU, 2007; LI, JIANG, FU et al., 2004; KADIOGLU, TAKCI, LEVENT et al., 2003; NOJIRI, MATSUMOTO, CHIBA et al., 2005; ACHARYA, DORJE and SRIVASTAVA et al., 2010; KANG, SONG, LEE et al., 2011; AMONOO-KUOFI, 1995; SINGEL, PATEL and GOHIL, 2004; OLSEWSKI, SIMMONS, KALLEN et al., 1990; WOLF, SHOHAM, MICHAEL et al., 2001; MAALY, SAAD and HOULEL, 2010).

Lumbar vertebral pedicle morphometric characteristics in Mexican population behave in a similar manner in vertebrae $\mathrm{Ll}$ to L4 as in other populations studied (Figure 3). L5 vertebras exhibit the most evident variations in their dimensions in the different populations studied and should be given special importance, prior to a surgical approach (Figure 3 ).

Pedicle width was lower than pedicle height in all vertebral levels studied. This determines the minimum diameter of the transpedicular screw and represents the measurement with the greatest prognostic value to prevent pedicle expansion or fracture due to incorrect choice of the pedicle implant. Some authors claim that pedicle height should not be considered as a morphometric parameter for proper selection of a transpedicular screw (MAILLOT and WOLFRAM-GABEL, 1993).

Table 2. $P$ values obtained by comparing mean pedicle width, height, and length using Student's $t$ test.

\begin{tabular}{cccc}
\hline Group comparison & Pedcile width & Pedicle height & Pedicle length \\
\hline L1 vs L2 & NS $(0.25)$ & NS $(0.32)$ & NS $(0.55)$ \\
L2 vs L3 & 0.03 & NS $(0.21)$ & 0.05 \\
L3 vs L4 & 0.05 & NS $(0.16)$ & NS $(0.23)$ \\
L4 vs L5 & 0.001 & 0.001 & NS $(0.30)$ \\
\hline
\end{tabular}

NS: not significant $(P>0.05)$. 
CASTRO-REYES, C. D., MORALES-AVALOS, R., VÍlCHEZ-CAVAZOS, F. et al.

Table 3. Pedical cortical width ( L1 to L5) obtained in studies performed with different world populations. Results are expressed in millimeters \pm SD.

\begin{tabular}{|c|c|c|c|c|c|c|}
\hline Population (author, year) & Method & Ll & L2 & L3 & $\mathrm{L4}$ & L5 \\
\hline Chinese (LÍEN, LIOU and WU, 2007) & Direct & $6.4 \pm 1.6$ & $7.4 \pm 1.7$ & $9.3 \pm 1.9$ & $11.6 \pm 2.1$ & $17.5 \pm 2.6$ \\
\hline Chinese (LI, JIANG, FU et al., 2004) & CT & $7.9 \pm 1.4$ & $8.7 \pm 1.2$ & $10.2 \pm 1.7$ & $11.5 \pm 1.2$ & $13.7 \pm 2.3$ \\
\hline $\begin{array}{l}\text { Spanish (OLMOS, VILLAS TOMÉ, } \\
\text { BEGURISTAN GURPIDE et al.,2002) }\end{array}$ & CT & --- & --- & $8.7 \pm 2.2$ & $11.5 \pm 2.1$ & $16.3 \pm 2.5$ \\
\hline $\begin{array}{l}\text { Turkish (KADIOGLU, TAKCI, } \\
\text { LEVENT et al., 2003) }\end{array}$ & Direct & $6.4 \pm 2.0$ & $6.6 \pm 2.3$ & $8.6 \pm 3.8$ & $10.8 \pm 3.3$ & $12.4 \pm 2.4$ \\
\hline $\begin{array}{l}\text { Mexicans (URRUTIA VEGA, } \\
\text { ELIZONDO-OMAÑA, DE LA } \\
\text { GARZA-CASTRO et al., 2009) }\end{array}$ & CT & $7.8 \pm 1.3$ & $8.2 \pm 1.4$ & $9.5 \pm 1.0$ & $10.7 \pm 0.6$ & $14.3 \pm 1.8$ \\
\hline $\begin{array}{l}\text { Japanese (NOJIRI, MATSUMOTO, } \\
\text { CHIBA et al., 2005) }\end{array}$ & Direct & $7.4 \pm 2.0$ & $7.8 \pm 1.7$ & $9.1 \pm 1.7$ & $10.1 \pm 1.7$ & $11.1 \pm 1.7$ \\
\hline $\begin{array}{l}\text { Indians (ACHARYA, DORJE and } \\
\text { SRIVASTAVA, 2010) }\end{array}$ & Direct & $7.2 \pm 0.93$ & $7.6 \pm 0.84$ & $8.9 \pm 1.1$ & $11.1 \pm 1.0$ & $13.9 \pm 1.1$ \\
\hline $\begin{array}{l}\text { Koreans (KANG, SONG, } \\
\text { LEE et al., 2011) }\end{array}$ & CT & $8.1 \pm 1.7$ & $8.5 \pm 1.5$ & $10.0 \pm 1.7$ & $11.5 \pm 2.0$ & $16.5 \pm 2.4$ \\
\hline Arabs (AMONOO KUOFI, 1995) & Direct & 8.7 & 9.0 & 10.5 & 11.1 & 12.5 \\
\hline $\begin{array}{l}\text { Indians (SINGEL, PATEL and } \\
\text { GOHIL, 2004) }\end{array}$ & Direct & $8.2 \pm 6.7$ & $8.5 \pm 6.5$ & $10.4 \pm 7.0$ & $13.5 \pm 7.0$ & $18.2 \pm 9.7$ \\
\hline $\begin{array}{l}\text { Americans (OLSEWSKI, VILLAS TOMÉ, } \\
\text { BEGURISTAN GURPIDE et al., 1990) }\end{array}$ & Direct & $7.7 \pm 1.9$ & $7.9 \pm 1.9$ & $9.6 \pm 2.4$ & $12.5 \pm 2.3$ & $18.4 \pm 3.6$ \\
\hline $\begin{array}{l}\text { Israelites (WOLF, SHOHAM, } \\
\text { MICHAEL et al., 2001) }\end{array}$ & CT & $5.6 \pm 1.3$ & $7.7 \pm 1.5$ & $8.9 \pm 1.9$ & $11.4 \pm 1.8$ & $13.7 \pm 2.2$ \\
\hline $\begin{array}{l}\text { Egyptians (MAALY, SAAD and } \\
\text { HOULEL, 2010) }\end{array}$ & CT & $6.8 \pm 1.9$ & $8.8 \pm 1.4$ & $10.1 \pm 1.6$ & $12.9 \pm 1.8$ & $18.9 \pm 2.1$ \\
\hline $\begin{array}{l}\text { Mexicans (CASTRO-REYES, } \\
\text { MORALES-AVALOS, VÍLCHEZ- } \\
\text { CAVAZOS et al., 2015) This study. }\end{array}$ & Direct & $7.4 \pm 1.6$ & $7.8 \pm 1.7$ & $9.1 \pm 2.1$ & $10.7 \pm 2.4$ & $14.7 \pm 3.7$ \\
\hline
\end{tabular}

CT: Computerized tomography.

Outer pedicle width in different populations

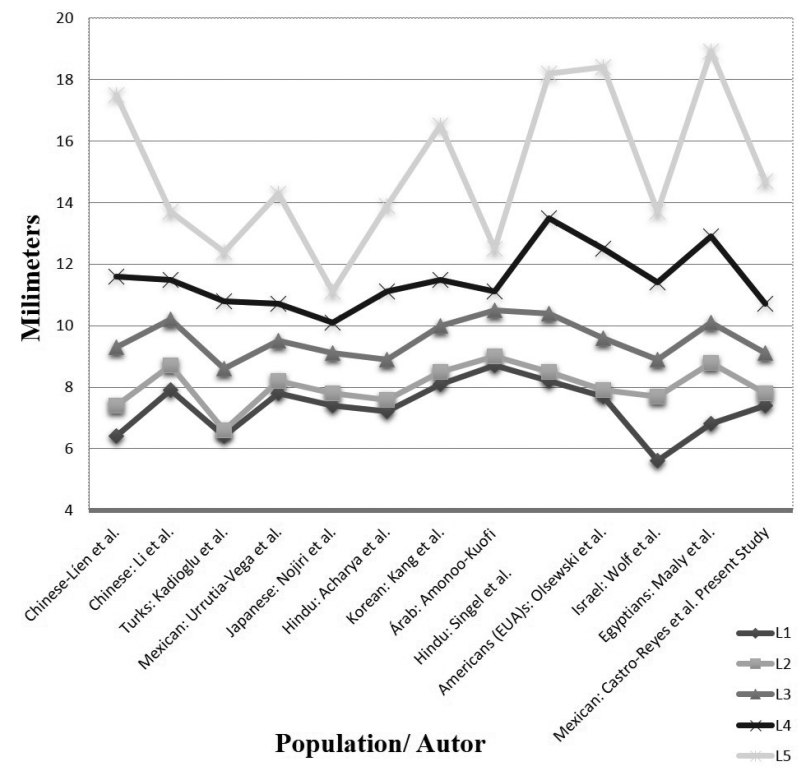

Figure 3. Pedicle width of lumbar vertebra pedicles obtained in studies performed in different populations.
(ZINDRICK, WILTSE, DOORNIK et al., 1987) recorded the highest number of measurements of lumbar pedicles with a total of 2,905 pedicles measured by CT and their study is the basis for subsequent morphometric studies. (SJÖSTRÖM, JACOBNSON, KARLSTRÖM et al., 1993) established, according to the data in their study of the lumbar pedicle, that screws with a diameter greater than $65 \%$ of the pedicle diameter deforms the cortical pedicle in $85 \%$ of cases. (MISENHIMER, PEEK, WILTSE et al., 1989) pointed out that the lateral cortical wall of the lumbar pedicle is prone to deformity or fracture because it is thinner than the medial cortical wall. (CHRISTODOULOU, APOSTOLOU, PLOUMIS et al., 2005 ) found that there is greater variation in the vertebrae L1, L2, and L5 between different races and ethnicities but established that in L3 and L4 there is only minimal variation. Our results and review of the literature concluded that the differences established by them could be lower and limited only to the pedicle of L5.

It has been found that the lumbar vertebral pedicle gradually and progressively decreases in length from Ll to L5. This determines a smaller cortical diameter and a greater pedicle length for upper lumbar vertebrae, and a greater pedicle width and a lower pedicle length in lower lumbar vertebrae (CHAWLA, SHARMA, ABHAYA et al., 2011). 


\section{Conclusion}

The present study accurately describes the morphometric characteristics of the lumbar vertebral pedicle in Mexican population. Based on these results, it can be stated that the lumbar transpedicular instrumentation systems currently available in Mexico are suitable for use in our population. However, a greater number of anatomical and imaging studies and a larger number of samples are necessary to analyze the morphometric characteristics of the lumbar vertebral pedicle in order to determine its true dimensions and establish variations according to age, gender, and vertebral level.

\section{References}

ACHARYA, S., DORJE, T. and SRIVASTAVA, A. Lower dorsal and lumbar pedicle morphometry in Indian population: a study of four hundred fifty vertebrae. Spine, 2010, vol. 35, n. 10, p. E378-E384. http://dx.doi.org/10.1097/BRS.0b013e3181cb7f2b. PMid:20431473.

AMONOO-KUOFI, HS. Age-related variations in the horizontal and vertical diameters of the pedicles of the lumbar spine. Journal of Anatomy, 1995, vol. 186, n. Pt 2, p. 321-328. PMid:7649830.

ARMAN, C., NADERI, S., KIRAY, A., AKSU, FT., YILMAZ, HS., TETIK, S. and KORMAN, E. The human sacrum and safe approaches for screw placement. Journal of Clinical Neuroscience : Official Journal of the Neurosurgical Society of Australasia, 2009, vol. 16, n. 8, p. 1046-1049. http://dx.doi.org/10.1016/j.jocn.2008.07.081. PMid:19442524.

CASTRO, WH., HALM, H., JEROSCH, J., MALMS, J., STEINBECK, J. AND BLASIUS, S. Accuracy of pedicle screw placement in lumbar vertebrae. Spine, 1996, vol. 21, n. 11, p. 1320-1324.

CASTRO-REYES, C.D., MORALES-AVALOS, R., VÍLCHEZCAVAZOS, F., DE LA GARZA-CASTRO, O., SALINAS-ZERTUCHE, A., AGUIRRE, P.O.M., CÁMARA-RODRÍGUEZ, L., VIDALTORRES, O., ELIZONDO-OMAÑA, R.E. and GUZMÁN-LÓPEZ, $S$. Morphometric characteristics of lumbar vertebral pedicles in Mexican population. Implications for transpedicular lumbar fusion surgery. Journal of Morphological Sciences, 2015. In press.

CHAWLA, K., SHARMA, M., ABHAYA, A. and KOCHHAR, S. Morphometry of the lumbar pedicle in North West India. European Journal of Anatomy, 2011, vol. 15, n. 3, p. 155-161.

CHAZONO, M., TANAKA, T., KUMAGAE, Y., SAI, T. and MARUMO, K. Ethnic differences in pedicle and bony spinal canal dimensions calculated from computed tomography of the cervical spine: a review of the English-language literature. European Spine Journal, 2012, vol. 21, n. 8, p. 1451-1458. http://dx.doi.org/10.1007/ s00586-012-2295-y. PMid:22526698.

CHRistodoulou, AG., APOSTOLOU, T., Ploumis, A., TERZIDIS, I., HANTZOKOS, I. and POURNARAS, J. Pedicle dimensions of the thoracic and lumbar vertebrae in the Greek population. Clinical Anatomy (New York, N.Y.), 2005, vol. 18, n. 6, p. 404-408. http://dx.doi.org/10.1002/ca.20155. PMid:16015613.

FEMENIAS ROSELLÓ, JM., ESTELLA RIPOLL, GJ., RUBI JAIME, M. and LLABRÉS COMAMALA, M. Injury to the gonadal, renal and duodenal veins during pedicle screw extraction surgery. Revista Española de Cirugía Ortopédica y Traumatología, 2009, vol. 53, n. 5, p. 340-343. http://dx.doi.org/10.1016/j.recot.2009.01.005.

GÓMEZ DE LA RIVA, A., ISLA, A., PÉREZ-LÓPEZ, C., ORTEGA, R., FERNÁNDEZ-MIRANDA, JC. and HEREDERO, J. Causes of reoperations in patients with lumbar spinal stenosis treated with instrumentations. Neurocirugia, 2006, vol. 17, n. 3, p. 232-239, discussion 239. PMid:16855781.

KADIOGLU, HH., TAKCI, E., LEVENT, A., ARIK, M. and AYDIN, IH. Measurements of the lumbar pedicles in the Eastern Anatolian population. Surgical and Radiologic Anatomy: SRA, 2003, vol. 25, n. 2, p. 120-126. http://dx.doi.org/10.1007/s00276-003-0109-y. PMid:12748815.

KANG, KS., SONG, KS., LEE, JS., YANG, JJ. and SONG, IS. Comparison of radiographic and computed tomographic measurement of pedicle and vertebral body dimensions in Koreans: the ratio of pedicle transverse diameter to vertebral body transverse diameter. European Spine Journal: Official Publication of the European Spine Society, 2011, vol. 20, n. 3, p. 414-421. http://dx.doi. org/10.1007/s00586-010-1560-1. PMid:20803224.

LI, B., JIANG, B., FU, Z., ZHANG, D. and WANG, T. Accurate determination of isthmus of lumbar pedicle: a morphometric study using reformatted computed tomographic images. Spine, 2004, vol. 29, n. 21, p. 2438-2444. http://dx.doi.org/10.1097/01. brs.0000144355.50660.65. PMid:15507808.

LIEN, SB., LIOU, NH. and WU, SS. Analysis of anatomic morphometry of the pedicles and the safe zone for through-pedicle procedures in the thoracic and lumbar spine. European Spine Journal, 2007, vol. 16, n. 8, p. 1215-1222. http://dx.doi.org/10.1007/s00586-0060245-2. PMid:17180401.

MAALY, MA., SAAD, A. and HOULEL, MME. Morphological measurements of lumbar pedicles in Egyptian population using computerized tomography and cadaver direct caliber measurements. The Egyptian Journal of Radiology and Nuclear Medicine, 2010, vol. 41, n. 4, p. 475-481. http://dx.doi.org/10.1016/j. ejrnm.2010.10.002.

MAILLOT, C. and WOLFRAM-GABEL, R. Pedicles of lumbar vertebrae. Surgical and Radiologic Anatomy: SRA, 1993, vol. 15, n. 4, p. 295-300. http://dx.doi.org/10.1007/BF01627881. PMid:8128337.

MISENHIMER, GR., PEEK, RD., WILTSE, LL., ROTHMAN, SL. and WIDELL JUNIOR, EH. Anatomic analysis of pedicle cortical and cancellous diameter as related to screw size. Spine, 1989, vol. 14, n. 4, p. 367-372. http://dx.doi.org/10.1097/00007632-19890400000004. PMid:2718038.

MORALES-AVALOS, R., ELIZONDO-OMAÑA, RE., VÍLCHEZCAVAZOS, F., MARTÍNEZ-PONCE DE LEÓN, AR., ELIZONDORIOJAS, G., DELGADO-BRITO, M., CORTÉS-GONZÁLEZ, P., GUZMÁN-AVILÁN, RI., PINALES-RAZO, R., DE LA GARZACASTRO, O. and GUZMÁN-LÓPEZ, S. Vertebral fixation with a transpedicular approach. Importance of anatomical and imaging studies. Acta Ortopedica Mexicana, 2012, vol. 26, n. 6, p. 402-411.

NOJIRI, K., MATSUMOTO, M., CHIBA, K. and TOYAMA, Y. Morphometric analysis of the thoracic and lumbar spine in Japanese on the use of pedicle screws. Surgical and Radiologic Anatomy: SRA, 2005, vol. 27, n. 2, p. 123-128. http://dx.doi.org/10.1007/ s00276-004-0305-4. PMid:15645156.

OKUTAN, O., KAPTANOGLU, E., SOLAROGLU, I., BESKONAKLI, E. and TEKDEMIR, I. Determination of the length of anteromedial screw trajectory by measuring interforaminal distance in the first sacral vertebra. Spine, 2004, vol. 29, n. 15, p. 1608-1611.

OLMOS, MA., VILLAS TOMÉ, C., BEGURISTAN GURPIDE, JL. and ZUBIETA, JLZ. Morfometría vertebral en población española. Revista Española de Cirugía Ortopédica y Traumatología, 2002, vol. 46, n. 2, p. 158-164.

OLSEWSKI, JM., SIMMONS, EH., KALLEN, FC., MENDEL, FC., SEVERIN, CM. and BERENS, DL. Morphometry of the lumbar spine: anatomical perspectives related to transpedicular fixation. Journal of Bone and Joint Surgery, 1990, vol. 72, n. 4, p. 541549. PMid:2139030.

PRAKASH PRABHU, LV., RAJANIGANDHA, V., MANGALA, MP., ANU, VR. and GAJENDRA, S. Morphometry of vertebral pedicles: a comprehensive anatomical study in the lumbar region. International Journal of Morphology, 2007, vol. 25, n. 2, p. 393-406. 
SANTONI, BA., HYNES, RA., MCGILVRAY, KC., RODRIGUEZCANESSA, G., LYONS, AS., HENSON, MA., WOMACK, WJ. and PUTTLITZ, CM. Cortical bone trayectory for lumbar pedicle screws. The Spine Journal, 2008, vol. 9, n. 5, p. 200-208.

SINGEL, TC., PATEL, MM. and GOHIL, DV. A study of width and height of lumbar pedicles in Saurashtra region. Journal of the Anatomical Society of India, 2004, vol. 53, n. 1, p. 4-9.

SJÖSTRÖM, L., JACOBNSON O., KARLSTRÖM, G., PECH, P. and RAUSCHNING, W. CT analysis of pedicle and screws tracts after implant removal in thoracolumbar fractures. Journal of Spinal Disorders \& Techniques, 1993, vol. 6, n. 3, p. 225-231. http:// dx.doi.org/10.1097/00002517-199306030-00007.

URRUTIA-VEGA, E., ELIZONDO-OMAÑA, RE., DE LA GARZA-CASTRO, O. and GUZMÁN-LÓPEZ, S. Morphometry of Pedicle and Vertebral Body in a Mexican Population by CT and Fluroscopy. International. Journal of Morphology, 2009, vol. 27 , n. 4 , p. 1299-1303. http://dx.doi.org/10.4067/S071795022009000400052 .
WEINSTEIN, JN., SPRATT, KF., SPENGLER, D., BRICK, C. and REID, S. Spinal pedicle fixation: reliability and validity of roentgenogram-based assessment and surgical factors on successful screw placement. Spine, 1988, vol. 13, n. 9, p. 1012-1018. http:// dx.doi.org/10.1097/00007632-198809000-00008. PMid:3206294.

WOLF, A., SHOHAM, M., MICHAEL, S. and MOSHE, R. Morphometric study of the human lumbar spine for operation-workspace specifications. Spine, 2001, vol. 26, n. 22, p. 2472-2477. http:// dx.doi.org/10.1097/00007632-200111150-00015. PMid:11707713.

ZINDRICK, MR., WILTSE, LL., DOORNIK, A., WIDELL, EH., KNIGHT, GW., PATWARDHAN, AG., THOMAS, JC., ROTHMAN, SL. and FIELDS, BT. Analysis of the morphometric characteristics of the thoracic and lumbar pedicles. Spine, 1987, vol. 12, n. 2, p. 160-166.

Received April 24, 2014 Accepted June 7, 2015 